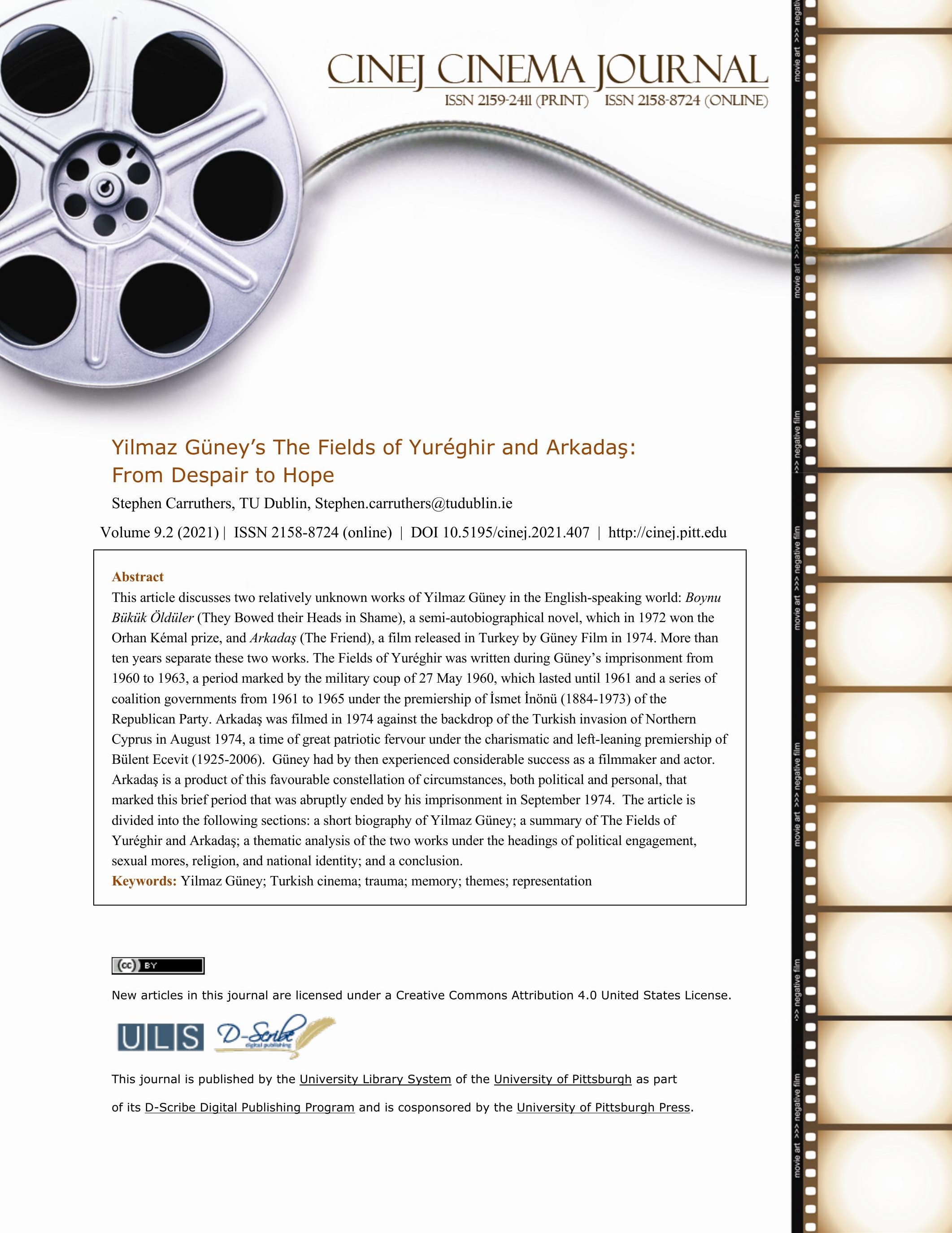




\section{Yilmaz Güney's The Fields of Yuréghir and Arkadaş: \\ From Despair to Hope}

\section{Stephen Carruthers}

\section{Introduction}

This article discusses two relatively unknown works of Yilmaz Güney in the English-speaking world: Boynu Bükük Öldüler (They Bowed their Heads in Shame), ${ }^{1}$ a semi-autobiographical novel, which in 1972 won the Orhan Kémel prize, and Arkadaş (The Friend), a film released in Turkey by Güney Film in 1974. More than ten years separate these two works. The Fields of Yuréghir was written during Güney's imprisonment from 1960 to 1963, a period marked by the military coup of 27 May 1960, which lasted until 1961 and a series of coalition governments from 1961 to 1965 under the premiership of İsmet İnönü (1884-1973) of the Republican Party. Arkadaş was filmed in 1974 against the backdrop of the Turkish invasion of Northern Cyprus in August 1974, a time of great patriotic fervour under the charismatic and left-leaning premiership of Bülent Ecevit (1925-2006). Güney had by then experienced considerable success as a filmmaker and actor. Arkadaş is a product of this favourable constellation of circumstances, both political and personal, that marked this brief period that was abruptly ended by his imprisonment in September 1974. The article is divided into the following sections: a short biography of Yilmaz Güney; a summary of The Fields of Yuréghir and Arkadaş; a thematic analysis of the two 
works under the headings of political engagement, sexual mores, religion, and national identity; and a conclusion.

\section{Biography}

Yilmaz Güney was born Yilmaz Pütün on 1 September 1937 in Yenice in the district of Karabük, in the province of Adana. His father, a Zaza, was from the Kurdish village of Sivérek in the South-East of Turkey. His mother was a Kurd from the village of Mup, near Lake Van. Güney started in the film industry as an assistant to the legendary director Atíf Yimaz (1925-2006) and went on to have a highly successful career as an actor in popular films throughout the 1960s, becoming known as the "Ugly King" (Ebiri, 2005, pp. 2-3). ${ }^{2}$

The 1960s are considered as the Golden Years of Turkish cinema. Colour films began in 1963 and dominated the market by 1967. In 1966, with 241 films, Turkish cinema was the fourth in the feature film production worldwide. During this period, a new kind of cinema emerged influenced by the social and political atmosphere of the country after the coup d'état of 27 May 1960 and the establishment of a progressive constitution in 1961, which brought a more relaxed atmosphere that nourished arts. Translations of diverse ideologies, including Marxism-Leninism, became available. With the steady development of industrialization and the growing national awareness in the so-called Third World, of which Turkey was a part, a certain euphoria for the 
arrival of a socialist revolution was felt, which was reflected in the films of the 1960s-70s, with Yilmaz Güney in Turkey, Ousmane Sembene in Senegal and Fernando Solanes in Argentina, for example, as pioneers (Dönmez-Colin, 2014, p. 5).

Following the 1960 military coup, Güney was sentenced to prison for communist propaganda on account of an essay he had written in 1955 entitled "Three Ways to a System of Equality" (Dönmez-Colin, 2014, p. 118). ${ }^{3}$ In 1970, Güney founded his own film production company, Güney Films, which produced over twenty films, notably Umut (Hope) (1970), which was screened at the $23^{\text {rd }}$ Cannes film festival but banned in Turkey until 1995 and catapulted Güney to leadership of the Turkish revolutionary cinema movement (Giles and Sahin, 1982).

Yilmaz Güney represents a breaking point between the popular cinema and political cinema in Turkey. His stories, characters and themes reflect the political 'angst' of the 1970s. He also has a unique place in Turkish cinema as the unattractive lead. The characters he portrayed were people on the margins: unemployed, poor vagabonds. Güney portrayed these lonely antiheroes who resisted the capitalist system in Turkey through their hanging on to life. In creating these heroes Güney leaned on the Turkish popular folk tales and their rebel hero, the urban lumpen proletariat, as a loser character with a specific body language and a peculiar vocabulary. In his later films, Güney's lumpen characters took on a darker political tone. They were no longer lonely Robin Hoods in the slums, the members of the lumpen proletariat 
who stole from the rich to give back to the poor. They were now rebels who fall victim to both the conservative traditions of society and state oppression during the military coup between 1980-1983. (Akser, 2009, p. 144)

During the period of martial law imposed from March 1971 until October 1973, Güney was sentenced in 1972 to seven years in prison for sedition. At the time he had been shooting Zavallilar (The Poor Ones), a film which would only be completed in 1974 (Dönmez-Collin, 2014, pp. 126-127). From 25 January to 17 November 1974, Ecevit of the Republican People's party was prime minister in an unstable coalition with the Islamist National Salvation party led by Necmettin Erbakan (1926-2011). Under a general amnesty for political prisoners granted by Ecevit, Güney was released from prison in May 1974, and started filming Arkadaş in the summer of 1974. On 15 July 1974, the National Guard in Cyprus overthrew President Archbishop Makarios III (1913-1977) and replaced him with Nikos Sampson (1935-2001) as de facto President, a puppet of the Greek Military Junta. On 20 July, Ecevit authorised Turkish military intervention, referred to as Attila I, on the side of the Turkish minority in Cyprus, which led to heavy fighting between Turkish forces and the Cypriot National Guard, covertly supported by Greek forces. ${ }^{4} \mathrm{~A}$ first cease-fire to facilitate peace negotiations in Geneva ended on the fourteenth of August with a renewed Turkish offensive, known as Attila II, which resulted in Turkish occupation of the Northern part of Cyprus. 
In September 1974, Güney was arrested on the charge of killing a local judge, Sefa Mutlu, who had insulted Güney and members of the film crew, including Güney's wife Fatoş, in a restaurant in the town of Adana while on location shooting scenes for his next film Endişe (Anxiety) (1974).

From that time on, Güney was in prison until his escape in 1981. While in prison, Güney continued to write scripts and co-direct, in collaboration notably with the director Zeki Ökten (1941-2009), on Sürü (The Herd) (1979) and Düssman (The Enemy) (1979), and with Serif Gören (b.1944) on Yol (The Road) (1982).

Yilmaz Güney was a rare artist who could blend political messages with commercially successful populist films. His Umut /The Hope (1970), extolled by the intellectuals of the cinematheque, is considered a turning point in Turkish cinema. Sürü / The Herd (1978), scripted by Güney while in prison and directed by Zeki Ökten, foregrounding the tragic story of the disintegration of a nomad family, is one of the best films of Turkish cinema. Yol/The Way (Şerif Gören, 1982), also scripted by Güney, shared the Palme d'or with Missing (Costa Gavras) at the Cannes film Festival, 1983. (Dönmez-Colin, 2014, p. 6)

On 12 September 1980, the Turkish military seized power from the civilian government led by Süleyman Demirel (1924-2015). In 1981 Güney's prison sentence was increased to over 100 years. Echoing the storyline in Yol, Güney fled in October 1981 by boat to Greece while on a temporary release from jail during Bayram, a Muslim religious holiday. After completing the 
edit of $\mathrm{Yol}$ in Switzerland, he was granted asylum by President Mitterrand, who had been elected President on 21 May 1981. In France, Güney made his final film Duvar (The Wall) (1983). He died of stomach cancer on 9 September 1984 and was buried at Père Lachaise Cemetery (Ebiri, 2005, pp. 1-12).

\section{The Fields of Yuréghir}

During his time in prison from 1960 to 1963, Güney wrote The Fields of Yuréghir which forms part of a tradition of peasant novel based in the villages of Anatolia.

The genre which might be called the peasant novel in Turkey appeared around 1949-50 with the publication of a number of works by young novelists of peasant stock, most of which had been trained in the so-called village institutes ... The Turkish village did not really become the focus of novelists' interests until the War of Independence (1912-1913), led by Mustafa Kemal Atatürk, who managed to rally all the life forces of the nation ... The ideologists of the sole party (the Republican People's Party) had decreed that Turkey would be a "classless society"; so it was at great personal risk that writers sought to explore the more conflictual aspects of reality, particularly if they wanted to depict the patriarchal structure of the village, which was morally and materially in the hands of the most influential men, and the exorbitant power that the large landowners and the agha held over the poor, landless peasant. It was a contrast that was almost Manichean in nature; but it was real, and it was played out in the 
theatre of village daily life day after day, in total contradiction to the idyllic picture painted by the administration. ... Turkish society, which was predominantly rural up to the 1950 s, was to undergo an abrupt change thereafter. The fifty thousand tractors and farm machines allocated to Turkey under the Marshall Plan could only benefit farmers of means - i.e., those who owned a large amount of arable land, possessed bank credit, and enjoyed the support of the Democratic Party, which came to power in 1950. Sharecroppers and poor peasants were forced to leave the villages, and approximately half of them went to live in slums on the outskirts of cities like Istanbul, Ankara and Izmit. This caused a wide-scale social upheaval, for the breakdown of the archaic system of production served both to reinforce social inequalities and to put an end to the closed economy of the forty thousand Anatolian villages. (Dino, 1986, pp. 266-274)

The Fields of Yuréghir is set around 1950, ${ }^{5}$ the year of election of the Democratic Party (Demokrat Parti) led by Celal Bayar as President and Adnan Menderes as Prime Minister, replacing the Republican Party (Cumhuriyet Halk Partisi) which had been in power since the founding of the Republic in 1923. At the beginning of the novel, Halil le Zaza returns after three years of military service to the village of Yénidjé in the province of Adana in Yuréghir where he grew up. He had been brought to the village by his mother after his father had been killed in a blood feud in his natal village of Kaldejik, near Sivérek in South-East Turkey. After the death of 
his mother, he had been taken on as a farm labourer by Kadir Agha, a wealthy farmer. Halil's life and those of the other characters in the novel working as tied workers in the village are characterised by grinding poverty, hard labour in the fields, and the lack of any prospect of betterment. ${ }^{6}$ The harsh routine of the village is occasionally interrupted by traditional customs, by the celebration of a marriage, the arrival of the rainmakers, or the annual trip to the coast. ${ }^{7}$ Hope for a better future, is portrayed by Güney through the character Rémzi, the young son of Kamber and Rébiche, and who can be seen as representing the childhood situation of Yilmaz Pütün. Despite the poverty and marital strife between his parents, and the opposition of the agha who plans to use him as a tied labourer like his father, he succeeds in gaining a place at secondary school in a different village and later leaves with his parents to study in Adana. Only Rémzi escaped the enveloping atmosphere of sadness by his youth and character. He saw only too well the silent agitation that had seized the village. The empty houses. The doors left wide open. All those who had left with eagerness taking their meagre belongings, followed by their children and their dogs. The deserted houses, the farmyards, the abandoned fields, the red geraniums that faded in the desolation. The wind which entered by one side of the village to leave by the other. The shutters which clattered and banged. A door which creaked. Then a violent storm struck the empty rooves and streets. All of that was, in the 
imagination of Rémzi, cracked walls, flooded houses, the rain, the rain, and again the rain.

(Güney, 1983, p. 192)

Later in the novel, Halil's love for Eminé, the only daughter of an impoverished peasant family, is brutally tested. While lying unconscious in the fields with a fever, Eminé is raped by Sélime, the son of Hassan Agha. Sélime is killed on the spot by Omar, whose wife Halimé had before their marriage lost her virginity to Sélime. Hassan Agha incites his son Dourdou to burn down the house of Omar and Halimé, who are burnt alive. Eminé's mother, Azimé, beats her savagely, treating her as a whore, no longer able to marry since she has lost her virginity. Halil at first reacts in accordance with the customary prejudice.

Halil understood nothing of the words that assaulted his ears. He was furious with Eminé and recalled her long, dirty fingers, her black fingernails, and her scrawny neck. He imagined her breathing and groaning with pleasure under the body of Sélime, associating her with the customary behaviour of women from Tachetchikane ${ }^{1}$ (fn. 1: a village near Adana well-known for prostitution) who lift their legs in the air while wetting their fingers saying: "Go on, my boy, at it.!" (Güney, 1983, pp. 214-215)

Halil then heroically defeats an attempt to shoot him by two Zazas, who had killed his father and tracked him to Yénidjé. After many tribulations, Halil and Eminé are reconciled and at the end of 
the novel they elope to the city of Adana. Through the words of Halil, Güney encapsulated the reasons for the mass exodus of peasants from Anatolia to the cities, both in Turkey and abroad.

He realised that he had lived until then as if this exploitation was inevitable, his agha, the unique agha. He had to break those chains. Elsewhere there was the city of Adana, a job without agha, without fear and without oppression, the freedom to walk at certain times of day, to make friendships, to work for oneself, to escape from the animals. (Güney, 1983, p.

\section{Arkadaș}

Arkadas (The Friend) was filmed in the summer of 1974 and released the same year. "The

Friend is the least-appreciated film of Güney in the West, although its impact was very strong in Turkey. Many Turkish critics considered it an apposite documentation of the 'culture shock' the urban middle class encounters when faced with the other, the poor, abandoned to their destiny in their invisible villages" (Dönmez-Colin, 2014, p. 128). The choice of a bourgeois milieu as the principal setting in Arkadaş was exceptional for Güney and explains its muted critical reception.

Güney has never been known for his subtlety, but his indulgences are usually tempered by moments of surprising insight and tenderness, particularly in those films set among the rural Anatolian poor. The Friend's bourgeois setting thus becomes a liability for the director, as he allows the film to devolve into caricature. It is not without its moments of beauty or mystery - 
Güney the actor's gaze is characteristically hypnotic, and he gives one of his most complex performances here - but it is far from the masterpiece some anticipated. (Ebiri, 2005, p. 6)

The plotline is developed over two distinct geographic milieux: the vibrant bars and nightclubs in Istanbul and the affluent beach homes in the seaside town of Bayramoğlu, dramatically contrasted with a remote village in South-Eastern Anatolia.

Güney plays Âzem, a public worker who comes to visit his prosperous childhood friend Cemil (Kerim Asfar) amid the decadent tranquillity of an upper middle-class summer tourist village. The militant, class-conscious Âzem is angered by what he perceives as Cemil's selling out of his youthful activism and small-town-roots. He finds himself at odds with Cemil's petit-bourgeois wife and begins to try to indoctrinate the youth of the village into the class struggle. The film's idyllic, relatively conventional narrative style then gives way to a stylistically splintered, elliptical second half, much of it set among the rural poor, as Âzem takes Cemil back to their village, where Cemil begins to see the error of his ways and becomes increasingly suicidal. (Ebiri, 2005, p. 6)

By frequent use of extended scenes without dialogue, Güney depicts the chasm that separated the urbanised, westernised Turkey from the impoverished Anatolian village in terms of material possessions and access to basic facilities such as water, food, and electricity. While the children in Bayramoğlu are seen spending the day at play on the paved streets and beach, the village 
children lack the most basic amenities and are portrayed working alongside the adults in the fields. But Güney also shows the village's social cohesion and solidarity, that is lacking in Bayramoğlu, through the warmth of the welcome given to Âzem by the villagers on his return and the scenes of collective work with the herd and in the fields.

The first part of Arkadaş, which is the longer part of the film at over an hour, is shot in Istanbul and the surrounding beach town of Bayramoğlu.

Arkadaş, meaning 'friend' but also 'comrade' in the parlance of the period, is an odd entry in Güney's oeuvre. Structured as a 'rich girl-poor boy in love film', it is Güney‘s attempt to engage in class difference while staying true to one's commitments. It takes place in Bayramoğlu, a then up-and-coming resort towards the Asian end of Istanbul (Kumburgaz had the same attraction on the European end; both places had long lost their appeal). The scene in question, however, is not in Bayramoğlu but comes after a series of ethnographic shots of bourgeois decadence on the beach. In this scene, taking place in Çicek Pasaji (Flower Passage), Âzem, played by Güney himself, meets his old college friend Cemil (Kerim Afşar) for the first time in the film. Again, as if writing an ethnography, Güney documents the folksy quality of life in this celebrated drinking hole: beer in tall glasses, fried mussels, kokoreç (grilled intestines), accordion player Madam Anahit, drinkers and passers-by. In the 1970s, Çicek Pasaji was packed with students, intellectuals and after-work crowds, as it was the 
place-to-be for a conversation over beer. Built as 'Cite de Pera' in the 1870s, the likes of which are to be found in Milan and Paris, Çicek Pasaji is no longer a living venue but a renovated place, adorned with hanging flower pots and framed pictures of its celebrities, including the late Madam Anahit. As the neighbouring fish market has retreated under the attack of gift shops selling cheap traditions, the passage lost its crowd to the nearby Nevizade Street. After leaving Çicek Pasaji, Güney's camera lingers in yet another locale erased from Istanbul's cityscape, Sulukule, the lowbrow entertainment district, now marked for gentrification. "Arkadaş" reads like a dated ethnography of times and places gone by. (Soysal, 2011, p. 28)

At the end of the film, Âzem leaves Bayramoğlu to return to his life as a rural roads engineer, rejecting the westernised bourgeois lifestyle epitomised by Cemil and his wife Necibe. But his return to traditional rural life risks forsaking his own happiness. As he himself says to Cemil: "What will we do in the village, when everybody wants to go the city?" (Güney, 1974, 01:28:30).

The second location is an Anatolian village in the district of Aksaray where Âzem and Cemil grew up. After a violent confrontation between Âzem and Cemil's wife Necibe, where Âzem strikes Necibe and he is then beaten by Cemil, Âzem and Cemil seek reconciliation by travelling to their childhood village. When they arrive, life seems at first to be little changed from that 
portrayed in The Fields of Yuréghir. There are shots of poorly clad children running barefoot on earthen pathways, mud houses with straw rooves, carts with wooden wheels, and the dominant presence of the wealthiest farmer in the village, Muhittin Agha, Cemil's brother. However, there are several significant differences. Firstly, the developing mechanisation of rural Anatolia, ${ }^{8}$ which is portrayed in the novel as a threat to the livelihood of the farm labourers, is depicted in Arkadaş as a sign of progress. Muhittin Agha with Âzem's assistance has purchased a pump to extract water from an aquifer enabling him to grow vegetables and melons. This in turn has given him, alone of the villagers, the means to afford access to electricity. While he zealously guards his produce from the villagers, the scenes of the children playing in the water and the greenery enveloping the village shows this advance is of general benefit. Secondly, the geographic and social isolation of Yénidjé has now been eroded in Arkadaş by the development of roads and motorised transport. Tourists are seen visiting the village taking photos of the "misery" of the Anatolian rural life, already intimating its isolation will not survive for long. While Cemil is outraged by this exploitative tourism, Âzem perspicaciously remarks that if the misery of the village is ended so will the taking of pictures (Güney, 1974, 01:23:22). ${ }^{9}$ A third notable difference is in the depiction of emigrants return to their village after leaving for the big cities of Turkey. The migration of peasants from the Anatolian villages from the 1950s onwards to the shantytowns (gecekondu) springing up around the centres of Istanbul and Ankara created a 
burgeoning working class in these rapidly expanding cities with "half their populations living in shantytowns" by 1970 (Keyder, 1979). ${ }^{10}$ In The Fields of Yuréghir for those labourers who return to the village, as in the case of Halil after three years of military service, there is no improvement in their situation or prospects for the future. In Arkadaş, however, Cemil and Âzem offer proof that leaving the village can lead to professional and material success. In Cemil's case this material success comes at an existential personal cost in terms of social dislocation and moral dissoluteness, whereas Âzem returns to use his education and technical knowledge for the collective benefit of the village.

\section{Thematic Analysis}

\section{Political Engagement}

Güney's strength and influence as an actor and director is most pronounced in those films where his cinematic representation cannot be separated from his politics. "Yilmaz Güney represents a breaking point between the popular cinema and political cinema in Turkey. His stories, characters and themes reflect the political 'angst' of the 1970s." (Akser, 2009, p. 144). For the majority of contemporary Turkish directors working in the mainstream Hollywood tradition, politics took a backseat to entertainment. ${ }^{11}$ Akser argues parallels can be drawn between the work of Güney and "Third Cinema," as epitomized by the Battle of Algiers (1966), and the independent American director John Cassavetes (1929-1989), whose films displayed a similar 
level of political commitment and artistic and financial independence (2009, p. 147). Güney's periods of incarceration meant that from the beginning of the 1960s his career as a film maker and actor was conditioned by his personal experience of the oppression and suffering of those marginalised by the Turkish state. His genius was to harness these experiences into forms of artistic representation that captured the common people's "oral narratives of dissent" symbolised by his adoption of the name the "ugly king" and the "creation of his anti-capitalist lumpen revolutionary" (Akser, 2009, pp. 145-148).

The noble savage characters in Güney's films react to the wild capitalism in their idiom and performance. The lumpen proletariat created in Turkey in the 1960s and 1970s was due to displacement caused by rapid industrialization in the cities. Rural peasant laborers lost their jobs as machine oriented farming started. They had to leave for the cities in search of industrial jobs. The new environment had opportunities but also threats. Since land ownership came late to Turkey compared to western countries, state-owned unoccupied land was seized by new comers. Squatter housing erupted. (Akser, 2009, p. 148)

In The Fields of Yuréghir, the farm labourers only way of escaping exploitation and oppression at the hands of the local agha ${ }^{12}$ was flight to Adana. There is no organised resistance to the oppression by the aghas, only individual acts of rebellion that end in tragedy. Güney's political commitment is reflected in Arkadaş through Âzem's engagement with workers at the seaside 
town where he stays with Cemil, much to the displeasure of Cemil's wife and the local bourgeoise. In particular, Âzem persuades Halil, a disaffected youth first seen engaging in petty vandalism, to becomes increasingly politically active under his tutelage. Likewise, in the village scenes, Âzem is portrayed in political discussions with the herdsmen and village workers. "There is no secret that Yilmaz Güney’s films always have a leftist political ideology to it and Arkadaş is no different. Güney, like all master-film makers uses cinema as a tool to put forward a personal inner dilemma about the class difference and one's inability to change" (Kardozi, 2010). Indeed, it has been said that Arkadaş is "a film that criticizes western lifestyles from a Marxist point of view” (Kaya and Azak, 2015, p. 268). ${ }^{13}$

\section{Sexual Mores}

In The Fields of Yuréghir sexual mores are dictated by tradition. Loss of virginity outside of marriage is the defining taboo, exemplified by the violent physical mistreatment of Eminé by her mother Azimé, and by Halil's repeated expressions of repulsion and physical abuse after she lost her virginity outside of marriage, irrespective of the fact that she had been raped by the agha's son Sélime while unconscious in the fields due to a fever. ${ }^{14}$

In his novel Arkadaj Ishklan, Orhan Kemal notes how impossible it is for a woman who has been raped to be accepted in society again: "She is dirty now. No water can clean her any more". What these words indicate is that nothing but violence and murder can clean "the dirt" 
- not the dirt on the woman but on the family, since a woman's actions against honour also, and most importantly, disgrace her family. (Ince, 2009, p. 547)

In Arkadaş, the focus has shifted to the immorality of the Istanbul bourgeoise, portrayed through the 'open relationship' overtly pursued by Cemil and his wife among their circle of friends. But while Âzem express to Cemil his contempt for his friend's moral "degeneracy" (Güney, 1974, 01:03:13), reproaching him with his former adherence to traditional values, Âzem himself fails to abide by these values. In an early scene in Istanbul, himself and Cemil visit a nightclub with topless dancers and then are seen with two prostitutes. While Cemil takes full advantage of the situation, Âzem refuses to participate but does not abandon his friend for whom he effectively acts as accomplice. Later, at the beachside resort, under the jealous gaze of Melike, Azem returns to the house of Ahu, a family friend, where they have sex.

Through the four principal female characters in the first part of Arkadaş, Güney represents the diverse and contradictory situation of westernised Turkish women. Melike, the 18 year-old younger sister of Cemil's wife Necibe, had been sent by Cemil to finishing school in Switzerland, is liberal but naïve. She and Güney, who is twelve years older than her, engage in a romantic, but platonic, relationship. When she interrogates Âzem about Marxist terminology she has overheard in his conversations of with workers in the town, her age and lack of experience precludes any real engagement by Âzem. Samra, the daughter of family friends, is portrayed as a 
politicalyy conscious and strong-minded woman. She reacts resolutely when taken to task by

Celim for her subversive reading, including books by the Bulgarian communist Georgi Dimitrov

(1882-1949) and the Franco-Hungarian Marxist theoretician Georges Politzer (1903-1942). In a

meeting with Âzem in a left-wing café bookstore in Bayramoğlu, she is dismissive of her friend

Melike as a "nightingale unaware of the world" (Güney, 1974, 00:37:04). Cemil's wife Necibe is

portrayed as an adulterous and morally dissolute character, but Âzem's contempt for her leads

him into physical violence against her which is a mirror of the violence perpetrated against

women in The Fields of Yuréghir. Ahu, a single young woman with whom Âzem has a brief

sexual encounter but then abandons, also seems the victim of Âzem patriarchal values. On his

previous return to the village with Cemil, Âzem had been reproached by Muhittin for failing to

bring back a "good girl” (Güney, 1974, 01:15:32). Âzem's bachelor status remained an issue as it

was in The Fields of Yuréghir: "The unwedded are poorly viewed in the village, Halil," insisted

Kamber" (Güney, 1983, p. 193). But in light of the chasm between the lifestyle and education of

the women Âzem met at Bayramoğlu and the prevailing moral code in his home village, his

failure to form a lasting relationship is portrayed as inevitable.

\section{Religion}

Islamic religion does not feature prominently in the lives of the villagers in The Fields of

Yuréghir, with the exception of specific events such as the funeral of the labourer Hidir or the 
celebration of the end of Ramadan. Religion provided little relief from the suffering of the farm workers, as Mahmoute, devastated by the ill-fortune of his daughter Eminé, explained to his wife Azimé:

"Do you know what? You should take hold of God, starve him for three winters, then put a heavy pickaxe in his hands and make him work in the sun, eat at the same table as us and endure what we endure. Then it would be fitting to administer a sound beating so that he could not get out of bed for a month at least. Then you would see God transform himself into a gentle lamb who would no longer recognise himself. (Güney, 1983, p. 67)

A rigorously secular vision had dominated Turkish society since the founding of the Turkish republic in 1923 by Kemel Ataturk (1881-1938).

Islam was an important component of the old system, before its gradual demise during the republican era, when secular reforms abolished the caliphate, disestablished the institution of the ulema, rejected Islamic law and adopted a modified version of the Swiss Civil Code, Latinized the alphabet, and, in 1928, struck out the sentence in the constitution of 1924 which stated that Turks were of the Islamic faith. (Önal, 2014, p. 200)

This secularism was relaxed following the accession to power of the Democratic Party in 1950 under the premiership of Adnan Menderes. In the 1960s the production of religious themed films increased: "'The making of religious movies started in 1961 with $H z$. Ömer' in Adaleti (The 
Justice of Omar), and the number gradually increased, with 6 movies in 1965 and 28 movies in 1973'” (Önal, 2014, p. 204, citing Deniz Kandiyoti). This growth in religious movies paralleled the emergence in the 1970s of the Islamic National View (Milli Goruss) movement led by Necmettin Erbakan (1926-2011) (Önal, 2014, pp. 207-208). Islamic films and novels began to emerge that opposed the degeneracy of "westernised elites" to "pious Muslims," most notably Birles, en Yollar/Crossroads by Yücel Çakmaklı (1970), the "first film that introduced Islam to Turkish cinema as a counter ideology" (Kaya and Azak, 2015, p. 258). However, Güney eschewed any religious underpinnings to his movies, most notably in Umut (Hope) (1970), adopting a Marxist perspective that religion acts as a distraction for the oppressed: "He argues that religion just keeps people occupied and prevents them from realizing their own powers" (Önal, 2014, p. 205). In Arkadaş treatment of religious themes is absent. Lacking any such religious basis, Âzem's criticism of what he refers to as Cemil's moral "degeneracy" is reduced to the generality that such behaviour is "not being civilised" (Güney, 1974, 01:03:09). ${ }^{15}$

\section{National Identity}

Güney militated in favour of the rights of the Kurdish people throughout his life. However, his reference to Kurdish issues in his films was "tacit", not least because of the risk of censorship as in Settiy Han (The Bride of Earth) (1968) and Sürü (The Herd) (1978) (Ciftci, 2015, pp. 122- 
123). ${ }^{16}$ Only in Yol (The Way) (1982) did Güney specifically incorporate a reference to

Kurdistan and, as a result, the Turkish state banned the film until 1999.

"The Way was the first film in Turkey to feature Kurdish culture, use Kurdish folksongs, and depict Kurdish characters truly with their own identity. Moreover, as Fuat Sengül points out, it was also the first film to introduce "'Kurdistan" as a new cinematic space” (2013: 243)

(Cifti, 2015, p. 123).

In The Fields of Yuréghir the protagonist, Halil, is of Zaza descent, as was the father of Güney, a people closely associated with the Kurds.

A good illustration of the above is the 4-5 million Zaza people in Central Anatolia. In spite of their distinct national identity and ethnic consciousness, the Zazas have never claimed their separate existence, as they have for centuries been surrounded by the Kurds, the people with a homogeneous language and close culture. Therefore, in the "outer world " they have been always considered as a part of the Kurds, a so-called "Kurdish tribe". The national identity of the Zaza has always been under the shadow of the Kurdish ethnic and national prevalence, and during the last century and a half, it has been totally suppressed by the Kurd's political strivings manifested in numerous movements. (Arakelova, 1999, p. 397)

However, aside from its continuing relevance to the novel's plot as part of Halil's tragic family backstory, Halil's Zaza descent plays no significant role in his relations with the villagers in 
Yénidjé or with Eminé. The shared harsh working and living environment for the tied laboureres created bonds of class solidarity that superseded issues of ethnic and religious identity. In this sense, Güney was following the treatment of the Kurdish question in mainstream films and novels at the time. In particular, Yeşilçam films promoted a nationalist Turkish identity. Gönül Dönmez-Colin contends that Yeşilçam, the popular cinema of Turkey from the 1950s until the 1980s, 'ignored the ethnic mosaic of the country in favour of the official state policy of national identity based on homogeneity regardless of the differences in religion, ethnicity or sexuality'(2014, p. 15). Discussing this homogeneous character of Yeşilçam within the context of nationalist modernization of Turkey, Savaş Arslan argues that Yeşilçam, 'helped the Turkification of popular culture, in perhaps a more effective way than the republican reforms (Aydinlik, 2021, p. 122).

In Arkadaş, Güney transcended his Kurdish identity to speak to the Turkish people as a whole.

\section{Conclusion}

At first, The Fields of Yuréghir seems a more optimistic work than Arkadaş. Âzem's attempts to change Cemil fail, indeed Cemil is close to suicide, and his attempt to build a lasting relationship with Melike also fail. His attempts to instil Marxist ideas in the youth and worker of the seaside town, represented by Halil, seem cut short by his departure. In contrast, at the end of The Fields of Yuréghir, Halil and Eminé flee the village of Yénidjé under the cover of darkness for Adana to 
start a new life free of the constraints and prejudices of the village. However, this conclusion does not fit deeper analysis of the two works. The Fields of Yuréghir is focused on the past, Arkadaş on the future. The prospects for Halil and Eminé in the shantytowns of Adana are bleak, as reflected in Halil's lack of any concrete plan and Eminé's desolation at abandoning her parents, while for Âzem his return to rural Anatolia as a trained engineer with the opportunity to assist the local farmers, as he had done for Muhittin Agha, is marked by optimism for achieving change. In contrast to the despair that permeates The Fields of Yuréghir, the final shot of Arkadaş showing a close-up of Halil and Âzem shaking hands on his departure is a signal of hope. 


\section{REFERENCES}

Akser, M. (2009). Yilmaz Güney's beautiful losers: idiom and performance in Turkish political film. In D. Bayrakdar (Ed.), Cinema and politics: Turkish cinema and the new Europe, 14253. Cambridge Scholars Publishing.

Arakelova, V. (1999). The Zaza people as a new ethno-political factor in the region. Iran \& the Caucasus, 3(4), 397-408. http://www.jstor.org/stable/4030804

Armes, R. (1987). Third world film making and the west. University of California Press.

Aydinlık, Y. (2021). National fantasy, impossible gaze: the Kurdish question in popular Turkish cinema. Turkish Studies, 22(1), 120-40. https://doi.org/10.1080/14683849.2020.1743691

Cicek, O. (2016). Kurdish cinema in Turkey: Imprisonment, memory, and the archive. $\mathrm{PhD}$ Dissertation, State University of New York at Binghamton.

Çiftçi, A. (2015). The politics of text and context: Kurdish films in Turkey in a period of political transformation. PhD Dissertation, Royal Holloway, University of London.

Coryell, S. (1995). Yilmaz Güney : le cinéaste révolté." Cahiers d'études sur la Méditerranée orientale et le monde turco-iranien, 19. https://doi.org/10.4000/cemoti.1709

Daldal, A. (2013). The impact of neo-realism in Turkish intellectual cinema: The cases of Y1lmaz Güney and Nuri Bilge Ceylan. Academic Journal of Interdisciplinary Studies 2/9, 181-186. http://dx.doi.org/10.5901/ajis.2013.v2n9p181

Dino, G., \& Grimbert, J. (1986). The Turkish peasant novel, or the Anatolian theme. World Literature Today, 60(2), 266-275. https://doi.org/10.2307/40141696

De Bruijn, P. (2012). Islam goes Hollywood. An exploratory study on Islam in Turkish cinema. CINEJ Cinema Journal, 2(1), 19-41. https://doi.org/10.5195/cinej.2012.51

Dönmez-Colin, G. (2008). Turkish Cinema.: Identity, Distance and Belonging. Reaktion Books. 
Ebiri, B. (2005). Güney Yílmaz. Senses of Cinema, 37. www.sensesofcinema.com/2005/greatdirectors/guney/

Giles, D., \& Sahin, H. (1982). Yilmaz Güney: Revolutionary Cinema in Turkey. Jump Cut: A Review of Contemporary Media, 27, 35-37.

https://www.ejumpcut.org/archive/onlinessays/JC27folder/YilmazGuney.html

Güney, Y. (1983). Les Champs de Yuréghir (A. Depeyrat, Trans.). J-C. Lattès. (Original work published 1966).

Güney, Y. (Director). (1974). Arkadas. Güney Film.

Güngör, A. C. (2015). From past to present: A cognitive work on 'New Turkish Cinema'. CINEJ Cinema Journal, 4(1). https://doi/org/10.5195/cinej.2014.121

İnce, H. O., Yarali, A., \& Özsel, D. (2009). Customary killings in Turkey and Turkish modernization. Middle Eastern Studies, 45(4), 537-551. http://www.jstor.org/stable/40262688

Kaftan, E. (2000). Identity in Crisis: Turkish Cinema Post 1980. MA Thesis, York University.

Kaya, D. \& Azak U. (2015). Crossroads (1970) and the origin of Islamic cinema in Turkey. Historical Journal of Film, Radio and Television, 35(2), 257-276. http://dx.doi.org/10.1080/01439685.2015.1027557

Keyder, Ç. (1979). The political economy of Turkish democracy. New Left Review, 1(115).

Önal, H. (2014). From clichés to mysticism: Evolution of religious motives in Turkish cinema. Religions, 5(1), 199-218. https://doi.org/10.3390/rel5010199

Soysal, L. (2011). Friend/Arkadaş. Çiçek Pasaji, Galatasary, Istanbul. Istanbul locations, scene 8. In Ö. Köksal (Ed.), World Film Locations: Istanbul (pp. 28-29). Intellect Books.

\section{ENDNOTES:}


${ }^{1}$ The first edition was published under the title Boynu Bükükler in 1966. It was republished as Boynu Bükük Öldüler in 1971. It was published in French in 1983 as Les Champs de Yuréghir (The Fields of Yuréghir) with a translation by Alfred Depeyrat. All English translations are my own and taken from Les Champs de Yuréghir. The novel is referred to in this article as The Fields of Yuréghir.

${ }^{2}$ The Legend of the Ugly King (2017), directed by Hüseyin Tabak, provides valuable biographical information about Yilmaz Güney.

${ }^{3}$ On the book cover to the Turkish edition of Boynu Bükük Öldüler, Güney said at the time he wrote the essay he had not read any works by Marx or other communist writers.

${ }^{4}$ There is a brief scene in Arkadas which directly references the war, when tanks and armoured vehicles are seen driving past the impassive gaze of a local man.

${ }^{5}$ Part VI of the novel is entitled " 1950 ."

${ }^{6}$ The landless plight of the laborer's in The Fields of Yuréghir was not applicable to all of Anatolia. "As a result, in most Anatolian villages land remained divided in small plots without a landless peasantry, and with very few rich landlords. The dominant feature of the Anatolian village was a large layer of poor middle peasants: with a sufficient amount of land for the family's subsistence in normal years, a small surplus in good years, and difficulties in years of famine. Most owned a pair of oxen, and rudimentary tools. A landlord régime, with a single owner in a village and a large number of share-croppers, was not prevalent except in the East and the South-East of Anatolia, areas that had never been totally subjugated under Ottoman rule.” (Keyder). See also: Akser (2009, p. 145).

${ }^{7}$ The description in the novel of Eminé, a young village woman, bathing fully clothed but still assailed by feelings of immodesty (Güney, 1983, p. 161) can be starkly contrasted by the lengthy opening shot in Arkadaş where the women wearing bikinis palpably enjoy the seaside resort of Bayramoğlu.

8 "By the end of the decade [the 1960s], almost one-half of the land was cultivated with the aid of tractors, which-in the absence of cooperatives - had become a source of profit for a new group of agricultural capitalists who owned, leased out and operated the machinery. Other changes in production methods, irrigation and fertilisers were also under way, to some limited extent" (Keyder, 1979).

${ }^{9}$ The English translation of the Turkish dialogue in Arkadaş is taken from a version published online, opensubtitles.org: www.opensubtitles.org/en/subtitles/3725805/arkadas-en. The references to timing are also taken from this source.

${ }^{10}$ See: Erman, T. (2001). The politics of squatter (Gecekondu) studies in Turkey: The changing representations of rural migrants in the academic discourse. Urban Studies, 38(7), 983-1002. https://doi.org/ 10.1080/00420980120080131

${ }^{11}$ For a discussion on the relationship between "Hollywood Cinema," represented by "Yeşilçam" ("green pine"), a group of Turkish directors from the late 1950s to mid-1970s who constituted a "mainstream school in Turkish cinema," and the "New Turkish Cinema," led by Güney and dated from the release of Umut in 1970, see: Arif Can Güngör (2015, p. 142). However, Güngör sees the primary function of mainstream cinema inspired by Hollywood as ideological (2015, pp. 129-30). See also: Kaya and Azak (2015, pp. 26-61).

${ }^{12}$ Agha is generally used to refer to a rich village peasant (Dino \& Grimbert, 1986, p. 268). The word has a variety of usages, including at the time of the Ottoman Empire when it was “used for the commanders of the Sultan's regiments, notably the 
commander-in-chief of the janissaries, and also for the chief black eunuch - the head of the sultan's private household - among others" (Finkel, C. (2007). Osman's Dream: The Story of the Ottoman Empire (1300-1923). Basic Books); and a tribal chieftain in Kurdistan (see: Martin van Bruinessen. (1992). Agha, shaikh and state: The social and politicals structures of Kurdistan. Zed Books).

${ }^{13}$ Citing Mümtaz Soysal, 'Ayrrlan yollar [Splitting Roads]', Milliyet [Nationality], 3 February 1976, 2.

${ }^{14}$ Even in cases of rape, a woman may be regarded as guilty: Ince, H. O., et al. (2009). Customary killings in Turkey and Turkish modernization. Middle Eastern Studies, 45(4), 537-551, 538. JSTOR, www.jstor.org/stable/40262688

${ }^{15}$ Robert Musil (1880-1942), in his unfinished masterpiece A Man without Qualities, defines civilisation, in the words of the character Walter, as living "so as to make great philosophy and poetry possible" (S. Wilkins, Trans., 1997, Picador, p. 398).

${ }^{16}$ An example of such a "tacit" reference is the scene in Arkadaş when Âzem gives Melike a copy of the book of poems hasretinden prangalar eskittin (fetters worn out by longing) (1968) by the Turkish-Kurdish poet Ahmend Arif (1927-1991) which they then recite together. 